\title{
Youth Leadership Character Development at the Karang Taruna Organization in Karawang West Java
}

\author{
Very Sukma Firmansyah \\ verysukmafirmansyah@gmail.com \\ STKIP Purwakarta \\ Encep Sharif \\ encepsynur@gmail.com \\ Universitas Pendidikan Indonesia (UPI) Bandung \\ Yadi Ruyadi \\ yadiruyadi16@gmail.com \\ Universitas Pendidikan Indonesia (UPI) Bandung
}

\begin{abstract}
This study discusses the role of the Karang Taruna Organization Leader in Karawang Regency in building youth character. This study used descriptive qualitative method. Data collection techniques used 5 techniques, namely in-depth interviews, observation, internet, and literature study. The process of data analysis in this study, namely data collection, data reduction, data presentation, and drawing conclusions. The results of research in the field show that the role of the Karang Taruna Organization Leader in Karawang Regency can build the character of youth, but it cannot be maximized because there are several obstacles, namely finance, lack of coordination of the management, lack of activeness of the board and personal interests. The characters that can be built in the organization are religious, responsible, disciplined, independent, honest, trustworthy, caring for others, cooperation, self-confidence, creativity, never giving up, leadership, tolerance, and nationalism. The role of the Leader of the Karang Taruna Organization in Karawang Regency can have implications for the personal resilience of youth, especially Basic Education and Training, because other activities are not running effectively. The implications of basic education and training can build an independent personality, togetherness, self-confidence, sticking to principles, dynamic, creative, and never give up. especially basic education and training, because other activities are not running effectively. The implications of basic education and training can build an independent personality, togetherness, self-confidence, sticking to principles, dynamic, creative, and never give up. Especially basic education and training, because other activities are not running effectively. The implications of basic education and training can build an independent personality, togetherness, selfconfidence, sticking to principles, dynamic, creative and never give up.
\end{abstract}

Keywords: Youth Leadership Character, Karang Taruna Organizations

Abstrak: Penelitian ini membahas tentang peran Pemimpin Organisasi Karang Taruna di Kabupaten Karawang dalam membangun karkater pemuda. Penelitian ini menggunakan metode deskriptif kualitatif. Teknik pengumpulan data menggunakan 5 (lima) teknik, yaitu wawancara mendalam, observasi, internet, dan studi pustaka. Proses analisis data dalam penelitian ini, yaitu pengumpulan data, reduksi data, penyajian data, dan penarikan kesimpulan. Hasil penelitian di lapangan menunjukkan bahwa peran Pimpinan Organisasi Karang Taruna di Kabupaten Karawang dapat membangun karakter pemuda, namun belum bisa maksimal karena terdapat beberapa kendala, yaitu keuangan, koordinasi pengurus masih kurang, keaktifan pengurus masih 
kurang dan kepentingan pribadi. Karakter yang dapat dibangun di organisasi tersebut, yaitu religius, tanggung jawab, disiplin, mandiri, kejujuran, amanah, peduli antar sesama, kerja sama, percaya diri, kreatif, pantang menyerah, kepemimpinan, toleransi, dan nasionalisme. Peran Pimpinan Organisasi Karang Taruna Kabupaten Karawang dapat berimplikasi terbadap ketahanan pribadi pemuda khususnya Pendidikan dan Latihan Dasar (Diklatsar), karena kegiatan yang lain tidak berjalan dengan efektif. Implikasi dari Pendidikan dan Latiban Dasar (Diklatsar) dapat membangun kepribadian yang mandiri, kebersamaan, percaya diri, berpegang tegub pada prinsip, dinamis, kreatif dan pantang menyerah.

Kata Kunci: Karakter Kepemimpinan Pemuda, Organisasi Karang Taruna

\section{INTRODUCTION}

Youth development is an important program for every country in the world, because youth are the nation's greatest asset as well as the foundation of hope that will re-establish the nation's ideals, besides that youth are also part of the wheel of the times that are expected to become agents of change. The role and participation of youth is very important in building community welfare, so it cannot be denied that every country always tries to build the knowledge, skills, and character of youth. There is a proverb that says that whoever controls the youth, will control the future. Basically, youth has a central role for the progress of the Indonesian nation. The role and participation of youth today has not shown maximum results, when compared to youth in the pre- and postindependence era. Young people are currently experiencing a character crisis that is concerning. Zainudin Amali (Minister of Youth and Sports) when giving a welcoming speech at the Peak Commemoration of the 93rd Youth Pledge Day 2021, said that the task of today's youth is to be able to open their eyes beyond the boundaries of the world's contemporary walls, have character, capacity, innovation ability, high creativity, independent, inspiring and able to survive and excel in the face of global competition in order to welcome a better future of the world. This speech clearly illustrates the role of youth in building the nation from the past until now during the pandemic. Therefore, youth unity and character building are very important and must be considered.

It is as expressed (Safitri \& Kisworo, 2014) that youth organizations in Indonesia aim to gather youth workers and channel them into productive activities. Abuse of this situation of course exists, namely when the leaders of youth associations use their influence for their own interests and direct their groups for bad purposes. But under normal circumstances, the existing youth associations or organizations, in addition to being useful for contributing to the development of their country, also function as the development of social attitudes of youth. One of the youth association organizations is summarized in Karang Taruna. (Wenti, 2013) said Karang Taruna is a Youth organization in Indonesia and is a place for developing the social spirit of the young generation, 
Karang Taruna grows on awareness and a sense of social responsibility from the community and for the community itself, especially the younger generation in a village, sub-district area. or an equal social community, especially engaged in the fields of social welfare.

As in the fields of economy, sports, skills, religion and the arts in accordance with the purpose of establishing a youth organization to provide guidance and empowerment to youth in a village or region itself, as a youth social organization Karang Taruna is a forum or place for coaching and development. in an effort to develop economic, social, cultural activities by utilizing all the potential that exists in the community, both human resources and natural resources that are already available. However, the existence of a gender-related gap within a youth organization is mentioned in(Youth Organizations, 2008) that "youth-serving organizations usually lose many members when girls become teenagers." More or less affect the performance of the organization itself.

Even though an organization should be a place to create innovations from youth creativity, as written by (Prokkola \& Ridanpää, 2017) that "youth organizations 'function as a site for the production of particular sets of knowledge and meanings' around citizenship."

So that the roles and functions of youth organizations are slightly shifted, this is written by (Jones, Merriman, \& Mills, 2016)"In general, the role of youth organizations in shaping the individual and group identities of young people has been neglected. There has been a dearth, especially, of research on the key role played by youth organizations in shaping the political and cultural identities of youth in the various territories."

As mentioned (Gould \& Voelker, 2013) "Youth leadership is developmental. It is therefore critical to adjust your expectations for youths at various developmental stages." That youth leadership is the development of every phase of adolescent development. So that youth organizations should be a place to facilitate youth in terms of self-development, especially character development.

(Karagianni \& Montgomery, 2017) said apart from youth organizations, the school environment also has a role in the process of adolescent selfdevelopment. "Secondary school students have the ability to develop leadership skills via decision-making, getting along with others, learning the organization of self, selfawareness, and working with groups through taking part in many youth leadership organizations in school and/or community activities." Programs arranged by schools should have involvement in leadership programs, as stated by (Beana, Harlowb, \& Fornerisa, 2016) "involvement in leadership programs can lead to a variety of positive 
psychosocial outcomes such as increased responsibility, initiative, autonomy and leadership."

This is because the need to develop potential in every phase of adolescence is a necessity, one of which is to become more critical. (Oparinde, Agbede, \& Bariki, 2017) argues that "the need for building youth leadership is becoming more critical now since the present day society continues to grow and change with challenging demands for the future."

Youth participation in the development and development process is not a bad idea,(Hope, 2012) said "engaging the youth population fully is therefore no longer a choice but an imperative in the development process that is also recognized by the government."

It is believed that the development of leadership character in an organization is a continuous process. As said by (Wihak, Hately, Allicock, \& Lickers, 2007) that "organizations recognize that in indigenous culture, leadership development is a lifelong effort, intimately tied to community development."

Supporting activities in the community to achieve a goal is the desire of all people. For this reason, organizations were established to realize a desire to be achieved. Organizations are also needed to coordinate all available resources to get maximum results. This Youth Organization should get more attention from the community, government and related parties. Because lately many young people are getting less attention and it is difficult to express themselves, so we can see that what teenagers are doing today are things that are not expected by all parties.

Other than that, (Laka \& Reresi, 2021) revealed that Karang Taruna is a vehicle for youth involvement. The youth, in the history of the struggle of the Indonesian nation, have played an active role as the spearhead in delivering an independent, united, and sovereign Indonesian nation and state. However, along with the times, the political dynamics of the younger generation began. Wrong association is one of the causes of the younger generation falling into deviant behaviour. It is hoped that this deviant behaviour will not penetrate the younger generation as the nation's successors, because they are the ones who hold the relay of the nation's future leadership.

The fact has shown that the changing times which are marked by advances in science such as science and technology always result in social changes (Moerdiyanto, 2000). The sophistication of communication and information technology makes changes in society go so fast and they must follow it so as not to be left behind by other countries. Today, Indonesian society is a modern society that is very complex. (Gultom, 2019) this condition 
is caused by advances in technology, mechanization, industrialization, urbanization and consumptives which raises many social problems. Difficulty in (Laka \& Reresi, 2021) Social problems that are considered as sociopathic, are socially known as social pathologies such as behavioural deviations, deviant structures, deviated groups, social roles, status and incorrect symbolic interactions.

As an illustration of the figure of the young generation of Top Scott in Widhyharto in (Mufarriq, 2020) mentions eight aspects that equate youth as "next generation" namely: Freedom, Customization, Scrutiny, Integrity, Collaboration, Entertainment, Speed, Innovation (techno-literate), where the implementation is formed by expression or action.

In these eight aspects, it can be considered to represent the expression of youth's life today and in the future. The younger generation and the latest media will also appear in the form of new behaviours and mindsets as well. Such as: interacting with old-new identities and even being anonymous, being sensitive to surrounding conditions by becoming individual activists, on the other hand, they are capable of being copyright violators, as well as accessing sexual information without limits. (Widhyharto, 2014) Even now youth and the latest media have the potential to become a new social movement that can change government decisions to be canceled and vice versa from proposals in new media then become decisions in the virtual dimension (online) and the real world (offline).

The emergence of various problems that youths do for Indonesia on an ongoing basis also has the potential to disrupt national security. In addition to supervision from parents and schools, social interactions and healthy communities can neutralize the possibility of degradation of the nation's character for young people. The responsibility to play an active role in supervising and educating the moral character of youth is not only carried out by the government, the community, but youth related agencies must also take part in it.

In addition, the definition of youth organization is mentioned by (Redmond \& Dolan, 2014) namely "Youth leadership programs enable young people to build their leadership capacity to contribute to humanity not sometime in the future, but right now. Focusing on building a theoretical framework assists practitioners in developing programs that are evidence informed, and therefore, more likely to yield the desired outcomes."

North use (2004) in (Redmond \& Dolan, 2014) also mentions "outlines how some definitions view leadership as the focus of a group process, is the leader is the centre of group change and activity." From this definition, the 
youth organization is a youth association led by one of its members as the centre of activity and command. Then (Redmond \& Dolan, 2014) added that "A youth leader can be any young person involved in leadership. In this context, described youth leadership as 'learning, listening, dreaming, and working together to unleash the potential of people's time, talent and treasure for the common well'."

The professionalism of youth organizations is highly demanded as a social infrastructure organization because its role and function as a development service is considered very strategic. It is possible that there are still many youth organizations that do not meet professional requirements. Local governments in their function as technical advisors have an obligation to continuously improve the quality of youth organizations. This must be balanced with youth organizations in motivating them to develop their roles and functions optimally to achieve youth organizations. (Zeldin \& Camino, 1991) "Others have described youth leadership as a set of competencies that enable young people to lead. (Khan, S, \& R, 2009) defined the development of youth leadership 'as young people empowered to inspire and mobilize themselves and others towards a common purpose, in response to personal and/or social issues and challenges, to effect positive change'."

In the current fast current of modernization, youth who are part of the youth organization must change the new order in the institutional dimension. The expected changes should follow the currents of globalization and decentralization which can create very dynamic open challenges starting from the level of ideas to direct action among young people. (Redmond \& Dolan, 2014) "Leadership as a process through which a set of learned skills and competencies facilitate a process of change, then the possibility remains that every person is capable of becoming a leader which brings to light the invaluable potential of programs to teach these skills."

Data from the Karang Taruna Secretary of Karwang Regency shows that the leadership of Karang Taruna in the regions (sub-districts and villages) has not been maximized in building youth character, this is shown by the case of several unscrupulous Karang Taruna members committing extortion to residents in one village in Karawang Regency (Mud, 02 November 2021: news.detik.com).

According to Crosan (2016: 15) "A clear majority of the people we talked to seemed to agree that character was critically important to good leadership." From Crosan's opinion, it is known that character education is very important to be internalized into the leadership element, especially in the Karang Taruna organization. 
This is said to be very important because the character as the identity of the leader will be known by many people, as said by Hannah (2011:990) "we suggest that character represents a layered, complex hierarchical structure. We suggest that character should be viewed as being integrated within a leader's identity and therefore differentiated across a complex identity structure that is developed across a leader's life-span as the leader interacts and learns from assuming various social roles."

This is not without reason, because most communities do not pay more attention to character education in the element of youth leadership, as stated by Mortensen (2014:448) "communities do not typically effectively tap into or develop youth leadership potential. Youth development and leadership efforts are often kept separate from community development efforts (London et al., 2003). Furthermore, adults are often not supportive of youth involvement or do not know how to involve youth in meaningful leadership roles."

The character and credibility of leadership are two things that are related to each other. Character is a key determinant in the success of an organization. The role of character is a key factor in the rise and fall of nations, a nation can survive not because it is smarter or more sophisticated than other nations, but because of its inner strength. It is clear that, the character of leadership as one of the keys to the success of an organization. (Sahadi, Taufiq, \& Wardani, 2020) Character will allow for the emergence of trust, while trust will allow for the emergence of leadership.

The term character, as expressed by some experts. Albert Einstein's opinion "Most people say that it is the intellect which makes a great scientist. They are wrong: Is it character". Furthermore, Martin Luther King Jr., stated: "Intelligence plus character-that is the goal of true education". And Imam Ghozali, stated that: "Akhlaq character is a trait that is embedded/pierced in the soul and with that nature a person can spontaneously easily radiate attitudes, actions and deeds".

Then from some of the experts above, here will be described about the definition of character. In Bastaman's opinion, argues that: "Character is the actualization of potential from within and internalization of moral values from the outside which are part of his personality". Then in the opinion of Soemarno Soedarsono said that: "Character is the moral values that are imprinted in us, through experience, experiment, sacrifice, and environmental influences, become intrinsic values that manifest in the system of fighting power, which underlies thoughts, attitudes and behavior".

Talking about leadership, as stated by (Handayaningrat, 1996) that: "leadership is the ability to convince people to pursue their goals with passion. 
These people or subordinates will carry out their duties by being carried out by a leader, the organization will be successful if it is supported by the ability to direct and control the organization in achieving its goals. Leadership is an art. As in the opinion of John Pfiffner, suggests that: "leadership is the art of coordinating and providing encouragement to individuals or groups to achieve the desired goals".

From the two opinions of the experts above, it can be concluded that leadership is an art to coordinate, direct and control other people to work together to achieve predetermined goals or objectives in an organization. It is clear that leadership is a very important role in an organization.

Another opinion as expressed by (Slamet, 2002), states that: "leadership is an ability, process, or function in general to influence people to do something in order to achieve certain goals".

On the other hand, leadership is the essence of management. As Millet argues in (Sarwoto, 1994) which states: "management is the process of leading and launching the work of people formally organized as a group to achieve the desired goals".

A leader must be able to do something for the members of the organization he leads. As according to (Sulaksana, 2002)the role of leaders in the organization, among others; (1) Assist the group in achieving its goals; (2) Enable members to meet needs; (3) Realizing group values; (4) It is the choice of group members to represent their opinions in interactions with other group leaders; (5) Is a facilitator who can resolve group conflicts.

On the other hand, (Robinson, 1999) suggests that the roles that leaders need to perform are; (1) spark an idea or as a head; (2) provide information; (3) as a planner; (4) give suggestions; (5) activate members; (6) supervising activities; (7) encouraging them to achieve their goals; (8) as a catalyst; (9) representing the group; (10) assign responsibility; (11) create a sense of security, and as an expert in the field he leads.

With regard to organization, in simple terms the organization is a means, tool, appropriate or container rather than a group of people to work together to achieve a common goal. For more details, will be put forward by the opinion of experts. As opinion (Robbins, 1994) argues that: "an organization is a group of people who work together to achieve a common goal".

Furthermore, (Robbins, 1994), argues that: "organization is as a consciously coordinated social entity, followed by relatively continuous boundaries by clearly identifying the signs and always trying to achieve the goal or group of goals together. Then (Robbins, 1994) explain the 4 main principles 
above, namely; (1) Organizations are social entities consisting of humans and human groups; (2) The organization will always be directed to a certain goal, because the existence of that goal is the embodiment of the reason for the establishment of the organization; (3) The organization contains systems that are coordinated rationally in order to be able to achieve predetermined goals; (4) The organization has relatively clearly identified boundary signs, which determine which elements are part of the organization or not. (Widiatmaka, Pramusinto, \& Kodiran, 2015) argued that building the character of youth carried out by youth organizations is one of the roles performed by youth organizations. Law Number 20 of 2009 concerning Youth in Article 43 explains that youth organizations must have membership, management, secretarial and financial management, as well as articles of association and bylaws. Article 1 paragraph (1) also explains that youth are Indonesian citizens who enter an important period of growth and development aged 16 (sixteen) to 30 (thirty) years. Character building of youth through organizations is basically very effective, if the entire series of activities can run optimally.

(Suyadi, 2013) revealing character are universal values human behaviour which includes all life activities, whether related to God, oneself, fellow human beings or with the environment that is manifested in thoughts, attitudes, feelings, words, and actions based on religious norms, laws, etiquette, culture and customs. (Ambarita, 2013) explained that building the character (character building) of the younger generation is an effort to build the nation, so that youth character must be built, namely (1) a sense of love for God and the truth, (2) responsibility, discipline, and independence, (3) trust and honesty, (4) respect and courtesy, (5) compassion, caring and cooperation, (6) confident, creative, and unyielding, (7) fair and leadership, (8) humble, and (9) tolerance, love for the homeland, and love for peace. Character education is a solution to overcome the problem of the youth character crisis experienced by Indonesia today, so it is undeniable that every formal, non-formal and informal education path implements character education. (Majid \& Andayani, 2012) explains an effective character education strategy to build noble character, consisting of three stages, namely moral knowing/learning to know, moral loving/moral feeling, and moral doing/learning to do. Character is very important to build because it will directly or indirectly have implications for personal resilience.

(Soedarsono, 1997) explained that personal resilience is a derivative of national resilience, which starts at the national level and then descends into the personality of each individual. Personal resilience that needs to be developed and must be able to reflect the Indonesian human figure with the Pancasila personality has characteristics, namely (1) having self-confidence and adhering 
to principles, (2) having a dynamic, creative and unyielding spirit, and (3) having independence and longing for togetherness.

Moral values have the following characteristics: first, they are related to our responsibilities, moral values are related to the human person. The moral value is that this value is related to the responsible human person. Moral values mean that a person is guilty or not guilty because he is responsible. In moral values, freedom and responsibility are absolute requirements. Second, related to conscience. All values ask to be recognized and realized, but on moral values this demand is more urgent and more serious. Realizing moral values is an "appeal" and conscience. One of the hallmarks of moral values is that only these values give rise to a "voice"

At least, there are many factors that contribute to influencing the moral quality of youth. One of these factors; are exemplary parents, leaders and society. This example in Indonesian nature is considered rare. The occurrence of various negative behaviours carried out by youth, one of which is caused by a crisis of exemplary among the nation's leaders and organizational leaders. This condition makes the youth no longer care about advice because the examples of negative behaviour displayed by the political elite that are obtained by youth through the mass media are far more influential on their personal formation. As a result, we are unable to stem the negative culture.

In the process of growth and development, there is a young generation who suffers from social problems such as juvenile delinquency, drug and drug abuse, street children and so on, both caused by internal (internal) and external (external) factors. If this is not addressed immediately, it will threaten the existence and survival of the nation and state.

The decline in the role and quality of self occurs among the younger generation, creativity, willingness, and ability to develop thoughts to build a nation aimed at good and competent regeneration will experience obstacles. Therefore, it is necessary to have efforts, programs and activities that continuously involve the participation of all parties, families, educational institutions and the environment, this condition indicates that the character and morals of this nation are increasingly crumbling and if left unchecked will only lead to the destruction of the Indonesian nation. This requires all elements of society to jointly take an active role in organizing and improving the dignity, dignity and unity of the Indonesian nation, one of which can be achieved through organizing, because by being organized, it can form the soul of a good generation that is expected by the Indonesian people. By organizing, especially Karang Taruna has many advantages, if it is used as the spearhead in building the nation's character. The development of national character is not only done 
through education, but through community organizations such as Karang Taruna. A number of activities in the Karang Taruna organization can be a means to acquire a number of characters and develop the creativity of the younger generation. However, for some circles, Karang Taruna is considered a forum for young people who never have work performance. Others even cynically stated that as a mass organization formed by the New Order, it is no longer active.

The name Karang Taruna itself is still popular among young people. Because this institution is a forum for young people to be creative and develop themselves. Their potential is huge. It is associated with youthful energy which can be a positive force if developed and directed towards positive things. In addition, in terms of quantity, the number of young people in Indonesia is also very large. Therefore, Karang Taruna needs to be fostered and empowered again.

Karang Taruna as a very important organization in society, not only as an organization that is underestimated in today's era, most people interpret it as an organization that cannot develop, has no activities and has no role, village youth have the potential to be able to change the character of youth, develop character. youth who are religious and in accordance with the values of Pancasila as well as the welfare of the village and its citizens through various programs,

In the vision listed by the Karang Taruna Regency of Karawang, it is stated that creating superior youth cadres is by fostering the character of youth in Karawang. This is also reinforced in the Karang Taruna mission, one of which is to develop character building for the younger generation in Karawang Regency by conducting training and study activities.

Based on the results of interviews conducted with the chairman and secretary of the Karang Taruna organization as respondents, it indicated matters relating to the inculcation of moral values and character in Karang Taruna youth,

According to the field survey, in general, the Karang Taruna organization in Karawang Regency requires facilities and infrastructure to facilitate activities related to inculcating moral values and character building. The Karang Taruna organization is an organization in Karawang Regency as a place of observation because based on data obtained from respondents through interviews that the Karang Taruna organization is an organization that makes it easier for us to gain knowledge. The Karang Taruna office became a place of observation because in that office the Karang Taruna organization carried out discussion activities. Based on the results of observations made by researchers, 
the method used by the Karang Taruna organization is to increase knowledge for young people.

The documentation used to answer the formulation of the problem about how to instill moral values in the Karang Taruna organization is photographs when researchers make observations. The photos consist of photos during activities such as workshops, trainings, recitations and discussion activities at the Karang Taruna organization in Karawang Regency.

Based on the Minister of Social Affairs Regulation No. 25 of 2019 concerning Youth Organizations that the objectives of Karang Taruna are (a) to create awareness of social responsibility for every young generation in anticipating, preventing, and countering various social problems, especially among the younger generation. (b) develop the ability of the younger generation in the implementation of social welfare through social rehabilitation, social security, social empowerment, and social protection, (c) build the character of the young generation who are knowledgeable, have personality, are skilled, intelligent, innovative, and creative. (d) develop the potential and ability of the young generation, (e) develop the spirit and spirit of social entrepreneurship for the young generation towards independence in an effort to improve Social Welfare.

The function of the Youth Organization Regulation of the Minister of Social Affairs No. 25 of 2019 concerning Youth Organizations, namely: (a) administrative and managerial, (b) facilitation, (c) mediation, (d) communication, information, and education, (e) utilization and development of technology, (f) social advocacy. (g) motivation, (h) mentoring and (i) reporting.

The organizers of actual efforts to prevent social problems based on the results of research conducted using interview, observation, and documentation techniques prove that the inculcation of moral values and guidance to youth through Karang Taruna activities in Karawang Regency is carried out by holding workshops, PHBN activities, and monthly trainings and recitations. What is meant by a workshop activity is an activity carried out by the Karang Taruna management and in the workshop activity we discuss a problem.

The inculcation of moral values occurs through Youth Youth Organization activities which can be carried out in the form of activities such as: workshops, recitations, and youth training activities. Facilities and infrastructure in Karang Taruna activities are needed to instill understanding, cultivate and increase awareness of responsibility, and develop an entrepreneurial spirit. Moral values and character with the spirit of togetherness, the spirit of kinship, social solidarity can be achieved in the youth of Karang Taruna. The concept that 
moral values, thus requires a clear time-sharing system and workflow for the members involved.

\section{RESEARCH METHODS}

This research was conducted with a qualitative approach with a descriptive method. Data collection methods used include: 1). Interview method addressed to members of Karang Taruna in Karawang district, 2). Documentation method to strengthen the data obtained from interviews, aims to obtain data related to research problems, 3). This observation method aims to examine directly by visiting the object to be studied. To check the validity of the data, researchers used triangulation techniques by comparing observational data with interview data, comparing interview results with related documentation, checking the degree of confidence of several data sources with the same method.

\section{RESULTS AND DISCUSSION}

Character Development of Youth Organization Leadership in Karawang Regency, Answers Province.

In the vision listed by the Karang Taruna of Karawang Regency, it is stated that creating superior youth cadres is by fostering the character of youth in Karawang. This is also reinforced in the Karang Taruna mission, one of which is to develop character building for the younger generation in Karawang Regency by conducting training and study activities.

Based on the results of interviews conducted with the chairman and secretary of the Karang Taruna organization as respondents, it indicated matters relating to the inculcation of moral values and character in Karang Taruna youth,

Observations of researchers in the field, in general, about the organization of Youth Organizations in Karawang Regency, require facilities and infrastructure to facilitate activities related to inculcating moral values and character building. The Karang Taruna organization is an organization in Karawang Regency as a place of observation because based on data obtained from respondents through interviews that the Karang Taruna organization is an organization that makes it easier for us to gain knowledge. The Karang Taruna office became a place of observation because in that office the Karang Taruna organization carried out discussion activities. Based on the results of observations made by researchers, the method used by the Karang Taruna organization is to increase knowledge for young people. 
The documentation used to answer the formulation of the problem about how to instill moral values in the Karang Taruna organization is photographs when researchers make observations. The photos consist of photos during activities such as workshops, trainings, recitations and discussion activities at the Karang Taruna organization in Karawang Regency.

Based on the Minister of Social Affairs Regulation No. 25 of 2019 concerning Youth Organizations that the objectives of Karang Taruna are (a) to create awareness of social responsibility for every young generation in anticipating, preventing, and countering various social problems, especially among the younger generation. (b) develop the ability of the younger generation in the implementation of social welfare through social rehabilitation, social security, social empowerment, and social protection, (c) build the character of the young generation who are knowledgeable, have personality, are skilled, intelligent, innovative, and creative. (d) develop the potential and ability of the young generation, (e) develop the spirit and spirit of social entrepreneurship for the young generation towards independence in an effort to improve Social Welfare.

The function of the Youth Organization Regulation of the Minister of Social Affairs No. 25 of 2019 concerning Youth Organizations, namely: (a) administrative and managerial, (b) facilitation, (c) mediation, (d) communication, information, and education, (e) utilization and development of technology, (f) social advocacy. (g) motivation, (h) mentoring and (i) reporting.

The organizers of actual efforts to prevent social problems based on the results of research conducted using interview, observation, and documentation techniques prove that the inculcation of moral values and guidance to youth through Karang Taruna activities in Karawang Regency is carried out by holding workshops, PHBN activities, and monthly trainings and recitations. What is meant by a workshop activity is an activity carried out by the Karang Taruna management and in the workshop activity we discuss a problem.

\section{CONCLUSION}

The inculcation of moral values occurs through Youth Youth Organization activities which can be carried out in the form of activities such as: workshops, recitations, and youth training activities. Facilities and infrastructure in Karang Taruna activities are needed to instill understanding, cultivate and increase awareness of responsibility, and develop an entrepreneurial spirit. Moral values and character with the spirit of togetherness, the spirit of kinship, social solidarity can be achieved in the youth of Karang Taruna. The concept that 
moral values, thus requires a clear time-sharing system and workflow for the members involved.

\section{REFERENCES}

Ambarita, B. (2013). "Profesionalisme, Esensi Kepemimpinan, dan Manajemen Organisasi”. Jurnal Generasi Kampus Vol. 6, No. 2, , 6.

Beana, C., Harlowb, M., \& Fornerisa, T. (2016). Examining the importance of supporting youth's basic needs in one youth leadership programme: a case study exploring programme quality. International Journal of Adolescence and Youth, 1.

Fathurrochman, I., Siswanto, S., Anggraeni, R., \& Kumar, K. S. (2021). Pengadaan Sarana dan Prasarana Pendidikan dalam Menunjang Mutu Pembelajaran di SDN Lubuk Tua Kabupaten Musi Rawas. Jurnal Darussalam: Jurnal Pendidikan, Komunikasi dan Pemikiran Hukum Islam, 13(1), 65-75.

Gould, D., \& Voelker, D. K. (2013). Enhancing Youth Leadership Through Sport and Physical Education. Journal of Physical Education, Recreation \& Dance, 40.

Gultom, A. (2019). Konsumtivisme Masyarakat Satu Dimensi Dalam Optik Herbert Marcuse. Jurnal Pendidikan Nilai dan Pembangunan Karakter 2 (1), 7 13.

Handayaningrat. (1996). Pengantar Studi Ilmu Administrasi dan Manajemen. Jakarta: Gunung Agung.

Hope, K. R. (2012). Engaging the youth in Kenya: empowerment, education, and employment. International Journal of Adolescence and Youth Vol. 17, No. 4, 222.

Jones, R., Merriman, P., \& Mills, S. (2016). Youth organizations and the reproduction of nationalism in Britain: the role of Urdd Gobaith Cymru. Social \& Cultural Geography VOL. 17, NO. 5, 714-734, 715.

Karagianni, D., \& Montgomery, A. J. (2017). Developing leadership skills among adolescents and young adults: a review of leadership programmes. International Journal of Adolescence and Youth, 2.

Khan, L., S, H., \& R, A. (2009). Taking the Lead: Youth Leadership in Theory and Practice. The Young Foundation. 
294 |Tadbir : Jurnal Studi Manajemen Pendidikan, Vol. 5, No. 2, 2021

Laka, L., \& Reresi, M. (2021). Penanaman Nilai-nilai Moral pada Pemuda melalui Kegiatan Karang Taruna. Jurnal Penelitian Pendidikan PAncasila dan Kewarganegaraan Vo. 1 No. 1, 33.

Majid, A., \& Andayani, D. (2012). Pendidikan Karakter Perspektif Islam. Bandung: PT Remaja Rosdakarya.

Moerdiyanto. (2000). Peranan Pengurus Karang Taruna Berstatus Mahasiswa Dalam Meningkatkan Kinerja Organisasi. Journal of Molecular Biology Vol. 301,3 .

Mufarriq, M. U. (2020). Membentuk Karakter Pemuda Melalui Pencak Silat. Jurnal Khazanah Pendidikan Islam, 42.

Oparinde, K. M., Agbede, G. T., \& Bariki, M. E. (2017). Student/Youth Leadership Development in Contemporary Societies: A Review Attempt. Journal of Social Sciences, 15.

Prokkola, E.-K., \& Ridanpää, J. ( 2017). Youth organizations, citizenship, and guidelines for tourism in the wake of mass tourism in Finland. Citizenship Studies, VOL. 21, NO. 3, 359-377, 367.

Redmond, S., \& Dolan, P. (2014). Towards a Conceptual Model of Youth Leadership Development. Child and Family Social Work Journal.

Robbins, S. (1994). Teori Organisasi : Struktur, Desain \& Aplikasi. Jakarta: Arcan.

Robinson, G. (1999). Perilaku Organisasi Jilid I. Jakarta: PT Indeks.

Safitri, N., \& Kisworo, B. (2014). Partisipasi Pemuda Dalam Program Karang Taruna Desa. Journal of Non Formal Education and Community Emporwerment, 45.

Sahadi, Taufiq, O. H., \& Wardani, A. K. (2020). Karakter Kepemimpinan ideal Dalam Organisasi. Jurnal Moderat Vol. 6 No. 3, 3.

Sarwoto. (1994). Dasar Organisasi dan Manajemen. Jakarta: Ghalia Indonesia.

Slamet. (2002). Administtrasi Negara Sebuah Pedoman Kerja. Jakarta.

Soedarsono, S. (1997). Ketahanan Pribadi dan Ketahanan Keluarga Sebagai Tumpuan Ketabanan Nasional. Jakarta: PT Intermasa.

Sosial, P. M. (2019). Karang Taruna. Jakarta: Kementerian Sosial.

Sulaksana. (2002). Menuju Masyarakat Partisipatif. Yogyakarta: Kanisius.

Suyadi. (2013). Strategi Pembelajaran Pendidikan Karakter. Bandung: PT Remaja Rosdakarya. 
Wenti. (2013). Ejournal Pemerintahan Integratif. Eksistensi Karang Taruna dalam Aktivitas Kepemudaan (Studi Kasus di Desa Gunawan Kecamatan Sesayap Kabupaten Tana Tidung).

Widhyharto. (2014). Kebangkitan Kaum Muda dan Media Baru. Jurnal Studi Pemuda Vol. 3 (2), 145.

Widiatmaka, P., Pramusinto, A., \& Kodiran. (2015). Peran Organisasi Kepemudaan Dalam Membangun Karakter Pemuda Dan Implikasinya Terhadap Ketahanan Pribadi Pemuda. Jurnal Ketahanan Nasional, 183.

Wihak, C., Hately, L., Allicock, S., \& Lickers, M. (2007). Eagle and the Condor: Indigenous Alliances for Youth Leadership Development. Diaspora, Indigenous, and Minority Education, 144.

Youth Organizations. (2008). Child \& Youth Services, 129.

Zeldin, S., \& Camino, L. (1991). Youth leadership: linking research and program theory to exemplary practice. New Design for Youth Development, 10-15. 
296 |Tadbir : Jurnal Studi Manajemen Pendidikan, Vol. 5, No. 2, 2021

This page belongs to the TADBIR : Jurnal Studi Manajemen Pendidikan

TADBIR : Jurnal Studi Manajemen Pendidikan Vol. 5, No. 2, 2021

IAIN Curup - Bengkulu | p-ISSN 2580-3581; e-ISSN 2580-5037 